\title{
The in situ Assay of Candida albicans Enzymes during Yeast Growth and Germ-tube Formation
}

\author{
By SATYENDRA P. RAM, ${ }^{1}$ PATRICK A. SULLIVAN ${ }^{1}$ AND \\ MAXWELL G. SHEPHERD ${ }^{2 *}$ \\ Department of Biochemistry ${ }^{1}$ and Experimental Oral Biology Unit ${ }^{2}$ (Faculty of Dentistry), \\ University of Otago, Dunedin, New Zealand
}

(Received 1 March 1983)

\begin{abstract}
Conditions are described for the preparation of permeabilized cells of Candida albicans. This method has been used for the in situ assay of enzymes in both yeast cells and germ-tube forming cells. A mixture of toluene/ethanol/Triton X-100 (1:4:0.2, by vol.) at $15 \%(\mathrm{v} / \mathrm{v})$ and $8 \%(\mathrm{v} / \mathrm{v})$ was optimal for the in situ assay of glucose-6-phosphate dehydrogenase in yeast and germ-tube forming cells, respectively. The concentration of toluene/ethanol/Triton X-100 required for optimal in situ activity of other enzymes was influenced by the cellular location of the enzyme, growth phase and morphology. The membrane-bound enzymes (chitin synthase, glucan synthase, ATPase), cytosolic enzymes (glucose-6-phosphate dehydrogenase, isocitrate dehydrogenase, pyruvate kinase, phosphofructokinase, alkaline phosphatase, glucosamine-6-phosphate deaminase and $N$-acetylglucosamine kinase) and wall enzymes ( $\beta$-glucosidase and acid phosphatase) were measured and compared to the activity obtained in cell extracts. The pattern of enzyme induction and the properties of the allosteric enzymes phosphofructokinase and pyruvate kinase were measured in situ. Pyruvate kinase in situ was homotropic for phosphoenolpyruvate with a Hill coefficient of 1.9 and a $s_{0.5}$ of $0.6 \mathrm{mM}$, whereas in cell extracts, it had a Hill coefficient of 1.9 and a $s_{0.5}$ of $1.0 \mathrm{~mm}$. The $K_{\mathrm{m}}$ for ATP was $1.6 \mathrm{~mm}$ in cell extracts and $1.8 \mathrm{~mm}$ in permeabilized cells. In situ phosphofructokinase was homotropic for fructose 6phosphate $\left(s_{0.5}\right.$ of $2.3 \mathrm{~mm}$, Hill coefficient of 4.0$)$. The kinetic properties of pyruvate kinase and phosphof ructokinase measured in situ or in vitro were similar for both yeast cells and germ-tube forming cells.
\end{abstract}

\section{INTRODUCTION}

Permeabilized cells provide a convenient system for the assay of intracellular enzymes. The porosity of the cell membrane of the intact cell can be increased by several techniques which allow substrates not normally permeable to cells to enter the intracellular compartment(s). These conditions, designated by Reeves \& Sols (1973) as in situ, have been used with Escherichia coli for measuring the phosphotransferase system (Gachelin, 1969; Kornberg \& Reeves, 1972), enzyme induction (Pardee et al., 1959) and catabolite repression (Loomis \& Magasanik, 1964). The ease with which some fungal and mammalian cells can be permeabilized has made the in situ approach invaluable in the study of enzymes and DNA synthesis during growth (Felix, 1982; Castellot et al., 1978). The permeabilized cell as a system for biochemical study has recently been reviewed in some detail (Felix, 1982).

Permeabilized cells of Saccharomyces cerevisiae have been used for the study of glycolytic enzymes (Serrano et al., 1973; Gancedo \& Banuelos, 1979), $\alpha$-glucosidase (Adams, 1972), citrate synthase (Weitzman \& Hewson, 1973) and chitin synthase (Flores-Carreon et al., 1980). The conditions devised for studying a particular enzyme in situ may not be optimal for other enzymes

Abbreviations: Fru 6-P, fructose 6-phosphate; FDP, fructose 1,6-diphosphate; Glc-6-P dehydrogenase, glucose6-phosphate dehydrogenase; PEP, phosphoenolpyruvate; TET, toluene/ethanol/Triton X-100 $(1: 4: 0 \cdot 2$, by vol. $)$. 
in the same organism or for studies with different organisms (for review, see Felix, 1982). Often little attention has been given to assessment of the extent of permeabilization of the cells being studied. Permeabilized Candida albicans have been used for studies on trehalase (Arnold \& McClellan, 1975) and 1,3- $\beta$-glucanase (Notario, 1982). In this paper, the optimal conditions for permeabilizing different cell types (yeast cells and germ-tube forming cells) of Candida albicans are described. The activities of a number of intracellular enzymes were measured in permeabilized cells.

\section{METHODS}

Growth of organism, germ-tube formation and isotope labelling of cells. Yeast cells of Candida albicans ATCC 10261 and strain A72 obtained from Dr A. Cassone, Instituto Superiore di Sanita, Rome, Italy, were prepared in shake cultures using a glucose, salts and biotin medium (Shepherd \& Sullivan, 1976). Exponential phase yeast cells were harvested after $16 \mathrm{~h}$ growth. Yeast cell suspensions were starved for germ-tube formation by aerating $\left(100 \mathrm{~cm}^{3} \mathrm{~min}^{-1}\right.$ per $\left.100 \mathrm{ml}\right)$ for $24 \mathrm{~h}$ at room temperature and germ-tube formation was induced in GlcNAc as described by Shepherd et al. $(1980 a)$. Germ-tube forming cells were labelled by adding ${ }^{35} \mathrm{SO}_{4}\left[0.04 \mu \mathrm{Ci} \mathrm{ml} l^{-1}\right.$ $\left(1.48 \mathrm{kBq} \mathrm{ml}^{-1}\right)$ ] to the germination medium. The extent of germ-tube formation was assessed by light microscopy.

Preparation of permeabilized cells. Cells were permeabilized by a modification of the method of Serrano $e t$ al. (1973). Unless otherwise stated, cells were suspended in $0.1 \mathrm{M}$-imidazole/ $\mathrm{HCl}$ buffer, $\mathrm{pH} 7 \cdot 0$, containing $0.2 \mathrm{M}-$ $\mathrm{KCl}$ and $0.1 \mathrm{M}-\mathrm{MgCl}_{2}$ at $1.2-1.6 \times 10^{9}$ cells ml- Permeabilizing agents were added as indicated, and the suspensions were shaken at maximum speed on a wrist-shaker (Griffin and George Microid shaker) for $5 \mathrm{~min}$ at $18^{\circ} \mathrm{C}$. The cells were washed three times by centrifuging $(2500 \mathrm{~g}$ for $10 \mathrm{~min})$ with the buffer to be used in the enzyme assay. The washed cell suspensions were stored in the same buffer at $4{ }^{\circ} \mathrm{C}$. For pyruvate kinase kinetics the imidazole buffer was replaced with $0 \cdot 1 \mathrm{M}$-phosphate, $\mathrm{pH} 7 \cdot 0$. For the measurement of phosphofructokinase, the cells were suspended in $0.1 \mathrm{M}$-Tris $/ \mathrm{HCl}, \mathrm{pH} 7 \cdot 6$, containing $0.1 \mathrm{M}-\mathrm{KCl}, 0.01 \mathrm{M}-\mathrm{MgCl}_{2}, 7 \mathrm{~mm}-\beta$-mercaptoethanol and $10 \mathrm{~mm}-\left(\mathrm{NH}_{4}\right)_{2} \mathrm{SO}_{4}$. Unless otherwise stated, the permeabilizing agent used was toluene/ethanol/Triton X-100 $(1: 4: 0 \cdot 2$, by vol.) (TET). Yeast cells and 1 h germ-tube forming cells were permeabilized with $17 \%(\mathrm{v} / \mathrm{v})$ and $10 \%$ $(\mathrm{v} / \mathrm{v})$ of the reagent, respectively.

Preparation of cell extracts. Cells were suspended in the appropriate enzyme assay buffer at the concentration used for permeabilized preparations. Glass beads $(0.5 \mathrm{~mm})$ were added to a ratio of $1: 2(\mathrm{v} / \mathrm{v})$ and the suspension shaken at 4000 r.p.m. $(2 \times 30 \mathrm{~s})$ in a Braun homogenizer with cooling by compressed $\mathrm{CO}_{2}$. The glass beads were separated from the cell extract by centrifuging $(2000 \mathrm{~g}$ for $5 \mathrm{~min})$. The cell extracts for pyruvate kinase and phosphof ructokinase studies were chromatographed on a column $(9 \times 2.5 \mathrm{~cm})$ of Sephadex G-25 using $0.05 \mathrm{M}-$ phosphate, $\mathrm{pH} 7 \cdot 0$ and $0 \cdot 1 \mathrm{M}-\mathrm{Tris} / \mathrm{HCl}, \mathrm{pH} 7 \cdot 6$, respectively.

Enzyme assays. Acid and alkaline phosphatases (EC 3.1.3.2 and EC 3.1.3.1, respectively) were measured at $30^{\circ} \mathrm{C}$ using fixed time assays of $30 \mathrm{~min}$ and $10 \mathrm{~min}$, respectively. Each assay $(0.5 \mathrm{ml})$ contained $p$-nitrophenol phosphate $(6 \mathrm{mM})$ in $0.1 \mathrm{M}$-acetate buffer, $\mathrm{pH} 4.0$ (acid phosphatase) or $0.8 \mathrm{M}$-Tris/HCl buffer, $\mathrm{pH} 9 \cdot 0$, containing $0.1 \mathrm{M}-\mathrm{MgCl}_{2}$ (alkaline phosphatase). The reaction was stopped by the addition of $0.5 \mathrm{ml} 10 \%(\mathrm{w} / \mathrm{w})$ TCA and the tubes were chilled on ice. After the addition of $1.5 \mathrm{ml} 1.0 \mathrm{M}-\mathrm{NaOH}$, the tubes were centrifuged to remove denatured protein and the nitrophenol produced was measured at $420 \mathrm{~nm}\left(\varepsilon=16 \times 10^{3} \mathrm{~mol}^{-1} \mathrm{~cm}^{-1}\right)$.

$\beta$-Glucosidase (EC 3.2.1.21) was measured in $0 \cdot 1 \mathrm{M}$-potassium phosphate, $\mathrm{pH} 7 \cdot 0\left(30 \mathrm{~min}\right.$ at $30^{\circ} \mathrm{C}$ in a final volume of $0.5 \mathrm{ml}$ ) using $p$-nitrophenol- $\beta$-D-glucose at $6 \mathrm{~mm}$. The production of $p$-nitrophenol was measured as described above. Glucosamine-6-phosphate deaminase (EC 5.3.1.10) was assayed as described by Gopal et al. (1982a), chitin synthase (EC 2.4.1.16) as described by Chiew et al. (1980), and 1,3- $\beta$-glucan synthase (EC 2.4.1.34) as described by Gopal et al. (1982b).

ATPase (EC 3.6.1.3) activity was measured by a discontinuous method in an assay volume of $0.5 \mathrm{ml}$. Each assay contained $10 \mu \mathrm{mol} \mathrm{MgCl}, 100 \mu \mathrm{mol} \mathrm{KCl}$ and 5.0 $\mu$ mol ATP. Assays were performed in either $0 \cdot 2 \mathrm{M}$-acetate buffer, $\mathrm{pH} 5.6$ or $0.2 \mathrm{M}$-Tris $/ \mathrm{HCl}$ buffer, $\mathrm{pH} 9 \cdot 1$. The assay mixtures were incubated for $15 \mathrm{~min}$ at $37^{\circ} \mathrm{C}$, and the reaction was stopped by the addition of $0 \cdot 1 \mathrm{ml} 5 \%(\mathrm{w} / \mathrm{w})$ TCA. After neutralizing and centrifuging the assay mixture, the ADP formed was measured spectrophotometrically by the coupled pyruvate kinase-lactate dehydrogenase assay described by Hess \& Wieker (1974).

The following continuous enzyme assays were performed at $30^{\circ} \mathrm{C}$ in a spectrophotometer fitted with a jacketed cuvette compartment. Glucose-6-phosphate dehydrogenase (EC 1.1.1.49) was assayed essentially as described by Broad \& Shepherd (1970). Each assay (1.0 ml final volume) contained $0.50 \mu \mathrm{mol} \mathrm{Glc}-6-\mathrm{P}, 8 \cdot 0 \mu \mathrm{mol} \mathrm{MgCl}_{2}$ in $0.08 \mathrm{M}-\mathrm{Tris} / \mathrm{HCl}, \mathrm{pH} 7 \cdot 2$. NADP ${ }^{+}$isocitrate dehydrogenase (EC 1.1.1.42) was assayed by the method of Flavell \& Fincham (1968). Each assay (final volume of $1.15 \mathrm{ml}$ ) contained $0.2 \mu \mathrm{mol} \mathrm{NADP}{ }^{+}$and $1.8 \mu \mathrm{mol}$ isocitrate in $0 \cdot 16 \mathrm{M}$-potassium phosphate, $\mathrm{pH} 7 \cdot 0$ and $2 \cdot 0 \mathrm{~mm}-\mathrm{MgCl}_{2}$. Pyruvate kinase (EC 2.7.1.40) was measured by the coupled lactate dehydrogenase method (Hess \& Wieker, 1974). Each assay $(1.0 \mathrm{ml}$ ) was in $0 \cdot 1 \mathrm{M}$-phosphate buffer 
(pH 6.0) containing $0.1 \mathrm{M}-\mathrm{KCl}, 0.01 \mathrm{M}-\mathrm{MgCl}_{2}, 2.5 \mu \mathrm{mol}$ ADP, $2.5 \mu \mathrm{mol}$ PEP, $0.2 \mathrm{~mm}-\mathrm{NADH}$ and lactate dehydrogenase. The lactate dehydrogenase added was sufficient to give an extinction change of 2 extinction units $\mathrm{min}^{-1}$ upon the addition of excess pyruvate. 6-Phosphofructokinase activity (EC 2.7.1.11) was measured with a coupled assay system described by Racker (1947). The disappearance of NADH was followed at pH 7.6 in a $1.0 \mathrm{ml}$ assay system which contained $80 \mu \mathrm{mol}$ Tris $/ \mathrm{HCl}, 80 \mu \mathrm{nol} \mathrm{KCl}, 8 \mu \mathrm{mol} \mathrm{MgCl}, 2.0 \mu \mathrm{mol}$ Fru $6-\mathrm{P}, 1 \cdot 8 \mu \mathrm{mol}$ ITP, $0 \cdot 16 \mu \mathrm{mol} \mathrm{NADH}, 16.0 \mu \mathrm{mol}\left(\mathrm{NH}_{4}\right)_{2} \mathrm{SO}_{4}$ and $5.6 \mu \mathrm{mol} \beta$-mercaptoethanol. Sufficient rabbit muscle aldolase $(\sim 1.0$ unit), triose phosphate dehydrogenase $(\sim 0.1$ unit) and baker's yeast $\alpha$-glycerophosphate dehydrogenase $\left(\sim 1.0\right.$ unit) was added to each assay to give an extinction change of 1.6 units $\mathrm{min}^{-1}$ upon the addition of excess FDP.

Enzyme units. A unit of activity in all assays is the amount of enzyme which transforms $1 \mu \mathrm{mol}$ of substrate per min under the conditions of the assay. In this communication, all results are expressed on a cell number basis (i.e. units per $10^{10}$ cells). In growing yeast cells of $C$. albicans, $10^{10}$ cells is equivalent to $58 \mathrm{mg}$ dry weight. With the starved and $1 \mathrm{~h}$ germinating cells, $10^{10}$ cells are equivalent to 44 and $46 \mathrm{mg}$, respectively (Sundaram et al., 1981). For allosteric enzymes $s_{0.5}$ and $h$ are the substrate concentration for half maximal activity and the Hill coefficient, respectively.

Analytical methods. Oxygen uptake rates were measured in a Clarke type oxygen electrode (Rank Instruments, Cambridge, U.K.). Carbohydrate was determined by the method of Dubois et al. (1956), glucose by the glucose oxidase method of Lloyd \& Whelan (1969), and reducing sugar by the method of Lever (1973). Protein was determined by the Lowry method using crystalline bovine serum albumin as standard. Radioactively labelled material was counted in Bray's scintillant (Bray, 1960). Dry weights and cell numbers were determined as described by Sundaram et al. (1981).

\section{RESULTS}

\section{Preparation of permeabilized cells}

A variety of reagents were used to permeabilize yeast cells of $C$. albicans (Table 1). The effect of each agent was assessed by comparing the Glc-6-P dehydrogenase activity in a homogenate from an untreated batch of cells with the in situ activity. No Glc-6-P dehydrogenase was detected in cells treated with the detergents SDS $(2 \%, v / v)$ and Triton X-100 $(2 \%, v / v)$, but more than $90 \%$ of the control activity was recovered when the treated cells were homogenized. A similar result was obtained when cell suspensions were freeze-thawed up to eight times in buffer or treated with $50 \%(\mathrm{v} / \mathrm{v})$ ether, $15 \%(\mathrm{v} / \mathrm{v})$ dimethylsulphoxide, $10 \%(\mathrm{v} / \mathrm{v})$ toluene and $10 \%(\mathrm{v} / \mathrm{v})$ ethanol (data not shown). After nystatin and filipin treatment, less than $2 \%$ of the total Glc-6-P dehydrogenase activity could be measured by the in situ assay. A combination of toluene and ethanol was found to partially permeabilize C. albicans cells. When Triton X-100 was included, higher activities of Glc-6-P dehydrogenase could be measured. Table 1 shows that toluene/ethanol/Triton X-100 as a $1: 4: 0 \cdot 2$ (by vol.) mixture (TET) was the most effective agent tested for permeabilizing exponential phase yeast cells of $C$. albicans.

\section{Table 1. Preparation of permeabilized yeast cells of $C$. albicans}

Buffered yeast cell suspensions $\left(2.5 \times 10^{9}\right.$ cells in $\left.2.0 \mathrm{ml}\right)$ were treated with permeabilizing agents as described in Methods and the washed cells assayed in situ for Glc-6-P dehydrogenase activity. A control sample of cells homogenized contained 1.13 units per $2.5 \times 10^{9}$ cells.

Glc-6-P

\section{Permeabilizing} agent

Nystatin (300 units $\left.\mathrm{ml}^{-1}\right)$

Filipin $(400 \mu \mathrm{M})$

Toluene/ethanol $5: 4$

Toluene/ethanol $5: 4$

Toluene/ethanol/Triton X-100 5:4:1

Toluene/ethanol/Triton X-100 $3: 4: 1$

Toluene/ethanol/Triton X-100 2:4:1

Toluene/ethanol/Triton X-100 1:4:0.2

Toluene

Ethanol dehydrogenase

Concn in situ Homogenate

$(\%, v / v) \quad$ (units)

$10 \cdot 0 \quad 0.00$

$10 \cdot 0 \quad 0 \cdot 02$

$0.5 \quad 0.04$

$17 \cdot 0 \quad 0 \cdot 11$

$20 \cdot 0 \quad 0 \cdot 24$

$17.0 \quad 0.49$

$\begin{array}{ll}17.0 & 0.60\end{array}$

$17 \cdot 0 \quad 0.61$

$\begin{array}{ll}17.0 & 0.72\end{array}$

$10.0 \quad 0.00$

$10 \cdot 0$ activity $(\%)$

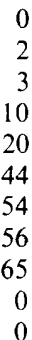


Table 2. Extraction of carbohydrate and protein from cells after treatment with TET

\begin{abstract}
Radioactively labelled cells were treated with different concentrations of TET and the protein and carbohydrate extracted into the permeabilizing buffer were analysed as described in Methods. A sample of the cell suspension was homogenized and analysed as a control. The results are shown from one representative experiment. The data are expressed as the amount extracted from $10^{10} \mathrm{cells}$. The yeast cell homogenate contained a total of $31 \mathrm{mg}$ protein and $47 \mathrm{mg}$ carbohydrate per $10^{10}$ cells, the germ-tube forming cell homogenate contained a total of $24 \mathrm{mg}$ protein and $42 \mathrm{mg}$ carbohydrate per $10^{10}$ cells.
\end{abstract}

(a) Yeast cells

$\begin{array}{ccc}\begin{array}{c}\text { TET concn } \\ (\%, \mathrm{v} / \mathrm{v})\end{array} & \begin{array}{c}\text { Protein } \\ (\mathrm{mg})\end{array} & \begin{array}{c}\text { Carbohydrate } \\ (\mathrm{mg})\end{array} \\ 0 & 1 \cdot 0 & 0 \cdot 3 \\ 5 & 1.4 & 1.5 \\ 10 & 1.6 & 2 \cdot 2 \\ 15 & 1.5 & 2 \cdot 5 \\ 20 & 2.0 & 2 \cdot 5\end{array}$

$\begin{array}{cc}\begin{array}{c}\text { Reducing } \\ \text { sugar } \\ (\mu \mathrm{g})\end{array} & \begin{array}{c}\text { Glucose } \\ (\mu \mathrm{g})\end{array} \\ 31 & 28 \\ 56 & 60 \\ 91 & 88 \\ 87 & 90 \\ 84 & 87\end{array}$

(b) $1 \mathrm{~h}$ germ-tube forming cells

$\begin{array}{cccccc}\begin{array}{c}\text { TET concn } \\ (\%, v / \mathrm{v})\end{array} & \begin{array}{c}\text { Protein } \\ (\mathrm{mg})\end{array} & \begin{array}{c}\text { Carbohydrate } \\ (\mathrm{mg})\end{array} & \begin{array}{c}\text { Reducing } \\ \text { sugar } \\ (\mu \mathrm{g})\end{array} & \begin{array}{c}\text { Glucose } \\ (\mu \mathrm{g})\end{array} & \begin{array}{c}10^{-3} \times \\ \text { Radioactivity } \\ (\mathrm{c} . \mathrm{p} . \mathrm{m} .)^{*}\end{array} \\ 0 & 1 \cdot 6 & 0 \cdot 2 & 50 & 0 & 0.5 \\ 4 & 2 \cdot 9 & 1 \cdot 9 & 350 & 94 & 100 \\ 8 & 3 \cdot 2 & 3 \cdot 2 & 500 & 115 & 120 \\ 12 & 4 \cdot 0 & 3 \cdot 2 & 860 & 310 & 150 \\ 16 & 5 \cdot 0 & 3 \cdot 9 & 1010 & 270 & 160 \\ \end{array}$

The amount of Glc-6-P dehydrogenase activity detected in yeast cells permeabilized with TET was not increased by the inclusion of $10 \mathrm{mM}-\beta$-mercaptoethanol, $50 \mu \mathrm{M}$-phenylmethylsulphonyl fluoride (PMSF) or both $\beta$-mercaptoethanol and PMSF, by shaking cells for longer than 5 min or by a second treatment with the permeabilizing agent. There was no significant difference in the extent of permeabilization over the temperature range 4 to $37^{\circ} \mathrm{C}$.

\title{
Removal of material from cells during permeabilization
}

Depending on the concentration of reagent employed, $1.0-6 \%$ of the carbohydrate was extracted from yeast cells (Table 2). All the reducing sugar was accounted for as glucose, but this represented only $6 \%$ of the total carbohydrate in the cells. Carbohydrate and protein extraction was higher ( $18 \%$ and $9 \%$ maximum, respectively) with germ-tube forming cells. Up to $30 \%$ of the total carbohydrate extracted was reducing sugar, but glucose accounted for less than $30 \%$ of this fraction. ${ }^{35} \mathrm{SO}_{4}$ was readily incorporated into germ-tube forming cells (Table 2). When these cells were permeabilized, maximum recovery of counts in the TET buffer $(65 \%)$ corresponded to maximum in situ Glc-6-P dehydrogenase activity (Fig. 1). SDS-PAGE of TET extracts of $C$. albicans cells revealed several bands of which five $(75,66,45,34$ and $18 \mathrm{kDal})$ comigrated with cytoplasmic proteins (data not shown). Intracellular Glc-6-P dehydrogenase, alkaline phosphatase, isocitrate dehydrogenase and pyruvate kinase were not released during the permeabilizing treatment. Permeabilized cells failed to respire and were not viable (less than $0 \cdot 1 \%$ viable counts of a control) when plated on yeast extract peptone medium (data not shown).

\section{Studies on enzymes in situ}

The data given represent typical examples of experiments which have been repeated at least three times with duplicate assays (standard error $<10 \%$ ). Variability between the different experiments was less than $20 \%$ with the exception of pyruvate kinase where the variation was up to $50 \%$. 

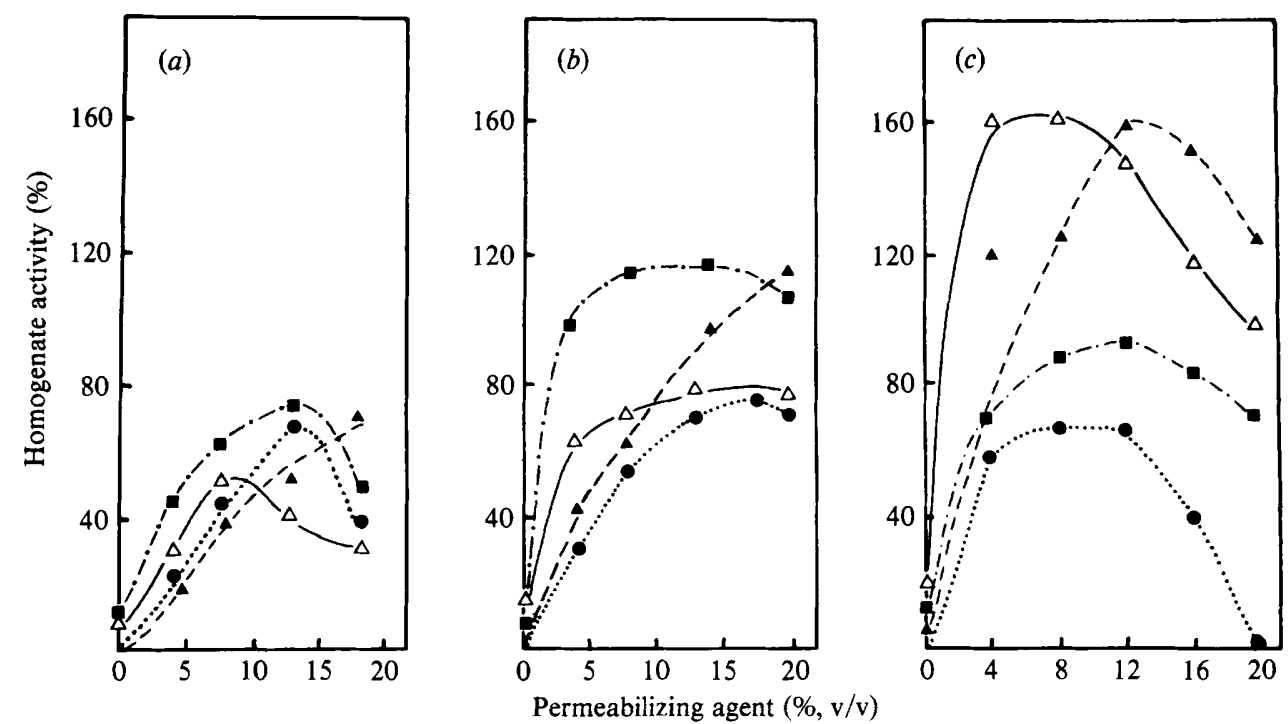

Fig. 1. The effect of varying the concentration of TET on the in situ assay of enzymes. Yeast cells $(a)$, starved cells $(b)$ and $1 \mathrm{~h}$ germ-tube forming cells $(c)$ were permeabilized with different concentrations of TET as described in Methods. Glc-6-P dehydrogenase (O), alkaline phosphatase ( $\mathbf{A}$ ), acid phosphatase $(\triangle)$ and $\beta$-glucosidase $(\square)$ were assayed in situ and activities expressed as percentages of the activity in homogenates from the appropriate cell suspension.

\section{Optimum conditions for in situ enzyme assays}

The in situ activities varied with the concentrations of permeabilizing agent and the type of cell used (Fig. 1). Yeast cells (Fig. $1 a$ ) showed optimal Glc-6-P dehydrogenase and $\beta$-glucosidase activities when cells were permeabilized with $10-15 \%(\mathrm{v} / \mathrm{v})$ TET. Alkaline phosphatase activity increased over the range of TET shown, but was optimal at $20-25 \%(\mathrm{v} / \mathrm{v})$. Maximum acid phosphatase was obtained with $7 \%$ (v/v) TET. Starved cells and germ-tube forming cells (Fig. $1 b, c)$ were more susceptible to the permeabilizing agent. With starved cells maximum $\beta$-glucosidase and acid phosphatase activities were obtained with $8-15 \%(\mathrm{v} / \mathrm{v})$ agent. Glc-6-P dehydrogenase activity was optimal around $15 \%(\mathrm{v} / \mathrm{v})$. Although alkaline phosphatase activity increased over the range of TET shown, maximum activity was assayed at $20-25 \%(\mathrm{v} / \mathrm{v})$. Glc-6-P dehydrogenase and acid phosphatase activities in germ-tube forming cells are fully exposed at $6 \%(\mathrm{v} / \mathrm{v})$ TET. Alkaline phosphatase and $\beta$-glucosidase are fully expressed by $12 \%$ (v/v) TET. High concentrations of TET (greater than $12 \%, v / v$ ) resulted in a decrease in all in situ activities with germ-tube forming cells. The concentrations of TET required for optimal in situ assays and the higher activities found for acid and alkaline phosphatases reflect differences in the cell membrane and cell wall of yeast and germ-tube forming cells.

In Table 3 and Fig. 1, the activity of several enzymes are compared. With exponential phase yeast cells, only $55-75 \%$ of the in vitro activities of Glc-6-P dehydrogenase, isocitrate dehydrogenase, acid phosphatase and pyruvate kinase could be detected in the permeabilized cells. Alkaline phosphatase and ATPase activity in permeabilized yeast cells was $70-100 \%$ of the in vitro activity. With starved yeast cells, the total in vitro isocitrate dehydrogenase, ATPase and alkaline phosphatase could be detected in situ; however, in situ assays accounted for only 70 $90 \%$ of Glc-6-P dehydrogenase, acid phosphatase and pyruvate kinase. In germ-tube forming cells, the activity of Glc-6-P dehydrogenase, isocitrate dehydrogenase and ATPase were found to be similar in permeabilized cells and homogenates, However, acid and alkaline phosphatase activities in situ were 1.6 times higher than the in vitro activity.

\section{In situ measurement of membrane-bound enzymes}

ATPase activity in permeabilized cells and homogenates was assayed at $\mathrm{pH} 5.6$ and $9 \cdot 1$. ADP formed in the assay was linear with time for $20 \mathrm{~min}$ and proportional to the cell number up to 
Table 3. Comparison of in vitro and in situ enzyme activities

Cells were treated with TET at concentrations which gave the maximum in situ activity for Glc-6-P dehydrogenase, acid and alkaline phosphatase (Fig. 1). For isocitrate dehydrogenase, pyruvate kinase and ATPase, the TET concentration was $17 \%(\mathrm{v} / \mathrm{v})$. Enzyme assays were performed as described in Methods and activities are expressed as units per $10^{10}$ cells. The in vitro activity is from a homogenate.

\begin{tabular}{|c|c|c|c|}
\hline Enzyme & $\begin{array}{l}\text { Homogenate } \\
\text { activity }\end{array}$ & $\begin{array}{l}\text { In situ } \\
\text { activity }\end{array}$ & $\begin{array}{l}\text { Ratio of } \\
\text { in situ: } \\
\text { in vitro } \\
\text { activity }\end{array}$ \\
\hline \multicolumn{4}{|l|}{ Glc-6-P dehydrogenase } \\
\hline yeast cells & $4 \cdot 50$ & $2 \cdot 90$ & 0.65 \\
\hline starved cells & $6 \cdot 04$ & $4 \cdot 61$ & 0.76 \\
\hline $1 \mathrm{~h}$ germ-tube forming cells & 4.01 & $4 \cdot 11$ & 1.02 \\
\hline \multicolumn{4}{|l|}{ Isocitrate dehydrogenase } \\
\hline yeast cells & $0 \cdot 32$ & $0 \cdot 18$ & 0.56 \\
\hline starved cells & $0 \cdot 33$ & $0 \cdot 34$ & $1 \cdot 03$ \\
\hline $1 \mathrm{~h}$ germ-tube forming cells & $0 \cdot 31$ & $0 \cdot 30$ & 0.98 \\
\hline \multicolumn{4}{|l|}{ Acid phosphatase } \\
\hline yeast cells & $0 \cdot 23$ & $0 \cdot 19$ & 0.65 \\
\hline starved cells & $0 \cdot 38$ & $0 \cdot 28$ & 0.74 \\
\hline $1 \mathrm{~h}$ germ-tube forming cells & $0 \cdot 27$ & $0 \cdot 50$ & $1 \cdot 60$ \\
\hline \multicolumn{4}{|l|}{ Alkaline phosphatase } \\
\hline yeast cells & $3 \cdot 64$ & $4 \cdot 08$ & $1 \cdot 12$ \\
\hline starved cells & $2 \cdot 40$ & $2 \cdot 46$ & 1.03 \\
\hline $1 \mathrm{~h}$ germ-tube forming cells & 1.50 & $2 \cdot 40$ & 1.60 \\
\hline \multicolumn{4}{|l|}{ Pyruvate kinase } \\
\hline yeast cells & $15-30$ & $13-25$ & $0.5-0.8$ \\
\hline starved cells & $15-31$ & $14-34$ & $0 \cdot 7-0 \cdot 9$ \\
\hline $1 \mathrm{~h}$ germ-tube forming cells & $14-30$ & $10-40$ & $0 \cdot 7-1 \cdot 03$ \\
\hline \multicolumn{4}{|l|}{ ATPase, pH 5.6} \\
\hline yeast cells & $1 \cdot 30$ & $1 \cdot 01$ & 0.77 \\
\hline starved cells & $1 \cdot 23$ & $1 \cdot 13$ & 0.92 \\
\hline $1 \mathrm{~h}$ germ-tube forming cells & $1 \cdot 23$ & $1 \cdot 20$ & 0.98 \\
\hline
\end{tabular}

$1.4 \times 10^{9}$ cells. The ATPase activity in four different cell samples at pH 5.6 and $\mathrm{pH} 9 \cdot 1$ was 1.3 $( \pm 0 \cdot 3)$ and $4 \cdot 2( \pm 0 \cdot 6)$ units per $10^{10}$ yeast cells, respectively. Dicyclohexyl carbodiimide $\left(760 \mu \mathrm{g} \mathrm{ml}^{-1}\right)$ and oligomycin $\left(150 \mu \mathrm{g} \mathrm{ml}^{-1}\right)$ had no effect on the pH 5.6 ATPase, but inhibited the $\mathrm{pH} 9 \cdot 1$ activity $(87 \%$ and $90 \%$, respectively). Chitin synthase and $1,3-\beta$-glucan synthase could be measured after treatment with either $4 \%(\mathrm{v} / \mathrm{v})$ TET or $4 \%(\mathrm{v} / \mathrm{v})$ toluene/ethanol $(1: 1)$. Higher concentrations of TET gave reduced activities. The 1,3- $\beta$-glucan synthase activity was 17.5 units ( $\mathrm{g}$ dry wt $)^{-1}$ with exponential phase yeast cells. Chitin synthase activity in yeast cells of strain A72 was $12.7( \pm 1.0)$ units (g dry wt) ${ }^{-1}$. The activity decreased in starved cells to 8.4 $( \pm 0.4)$ units (g dry wt $)^{-1}$, but was $33( \pm 1.0)$ units $(\mathrm{g} \text { dry wt })^{-1}$ in germ-tube forming cells. These changes in chitin synthase in situ are similar to the changes in the expressed activity of membrane preparations (Chiew et al., 1980).

In situ measurement of glucosamine-6-phosphate deaminase and GlcNAc kinase induction

Glucosamine-6-phosphate deaminase and GlcNAc kinase in C. albicans are inducible (Gopal et al., 1982a ; Shepherd et al., 1980 b). A low basal level of deaminase activity was present in noninduced cells (Table 4) but after incubation with $2.5 \mathrm{~mm}$-GlcNAc for $3 \mathrm{~h}$, a 22 -fold higher activity was found in permeabilized cells. Since C. albicans cells contain approximately $20 \%$ protein, the deaminase activity of 1.34 units per $10^{10}$ cells translates to 0.087 units $(\mathrm{mg}$ protein) $)^{-1}$. Values of 0.06-0.09 units (mg protein) $)^{-1}$ are obtained in cell extracts (Gopal et al., $1982 a)$. The activity of GlcNAc kinase in non-induced cells $\left(0.26\right.$ units per $10^{10}$ cells $)$ increased to $3 \cdot 1$ units per $10^{10}$ cells after $3 \mathrm{~h}$ incubation in $2.5 \mathrm{~mm}$-GlcNAc.

\section{Properties of pyruvate kinase in situ}

Pyruvate kinase in permeabilized cells showed similar characteristics to the enzyme in homogenates. When assayed with $2.5 \mathrm{~mm}$-ADP and PEP, activity at $\mathrm{pH} 6.0$ was twice that at 
Table 4. In situ assay of glucosamine-6-phosphate deaminase induction in C. albicans

Starved yeast cells of $C$. albicans were incubated with $2.5 \mathrm{~mm}$-GlcNAc at $30^{\circ} \mathrm{C}$. Portions $\left(5.8 \times 10^{9}\right.$ cells) were removed at $0,45,90,135$ and $180 \mathrm{~min}$ and permeabilized with TET at a final concentration of $9 \%(\mathrm{v} / \mathrm{v})$ in $0 \cdot 1 \mathrm{M}$-imidazole/ $\mathrm{HCl}$ buffer, $\mathrm{pH} 7 \cdot 0$, containing $0 \cdot 1 \mathrm{M}-\mathrm{KCl}$ and $10 \mathrm{mM}-\mathrm{MgCl}_{2}$. Glucosamine-6-phosphate deaminase was assayed as described in Methods.

$\begin{array}{rcc}\begin{array}{c}\text { Time } \\ \text { (min) }\end{array} & \begin{array}{c}\text { Glucosamine-6-phosphate } \\ \text { deaminase activity } \\ \text { units per } 10^{10} \text { cells }\end{array} & \begin{array}{c}\text { Fold increase } \\ \text { above basal } \\ \text { activity }\end{array} \\ 0 & 0 \cdot 06 & - \\ 45 & 0 \cdot 66 & 11 \\ 90 & 0 \cdot 84 & 14 \\ 135 & 1 \cdot 10 & 18 \\ 180 & 1 \cdot 34 & 22\end{array}$

Table 5. Kinetic properties of pyruvate kinase measured in vitro and in situ

Homogenates and permeabilized cells were prepared as described in Methods. Pyruvate kinase was measured in $(a)$ with $2.5 \mathrm{mM}-\mathrm{ADP}$, varying concentrations of phosphoenolpyruvate (PEP) $\pm 0 \cdot 2 \mathrm{mM}-$ fructose-1,6-diphosphate (FDP), and in (b) with $2.5 \mathrm{mM}$-PEP, varying ADP and $\pm 1.96 \mathrm{mM}-\mathrm{ATP}$. Hill plots were used to determine the apparent $s_{0.5}$ value for phosphoenolpyruvate and for the value of $h$. Lineweaver-Burke plots were used to determine the apparent $K_{\mathrm{m}}$ for ADP.

(a) Variable PEP concentration

\begin{tabular}{|c|c|c|c|}
\hline & \multicolumn{2}{|c|}{$s_{0.5}(\mathrm{mM}$ PEP $)$} & \multirow[b]{2}{*}{ No FDP } \\
\hline & No FDP & $0 \cdot 2 \mathrm{mM}$-FDP & \\
\hline \multicolumn{4}{|c|}{$1 \mathrm{~h}$ germ-tube forming cells } \\
\hline in vitro & $0 \cdot 50$ & ND & $2 \cdot 0$ \\
\hline in situ & $0 \cdot 54$ & 0.41 & $3 \cdot 4$ \\
\hline \multicolumn{4}{|l|}{ Yeast cells } \\
\hline in vitro & $0 \cdot 60$ & 0.40 & 1.9 \\
\hline in situ & 1.0 & 0.50 & 1.9 \\
\hline \multicolumn{4}{|c|}{ (b) Variable $A D P$ concentration } \\
\hline & & \multicolumn{2}{|c|}{$K_{\mathrm{m}}$ apparent (mM ADP) } \\
\hline & & No ATP & $1.96 \mathrm{mM}-\mathrm{ATP}$ \\
\hline \multicolumn{4}{|c|}{$1 \mathrm{~h}$ germ-tube forming cells } \\
\hline in vitro & & 1.6 & ND \\
\hline in situ & & 1.4 & ND \\
\hline \multicolumn{4}{|l|}{ Yeast cells } \\
\hline in vitro & & 1.6 & $1 \cdot 8$ \\
\hline in situ & & 1.8 & $2 \cdot 0$ \\
\hline
\end{tabular}

ND, Not determined.

$\mathrm{pH} 7 \cdot 0$. The activity was stable to storage at $4{ }^{\circ} \mathrm{C}$ and was stimulated by the following: $\mathrm{MgCl}_{2}$ (eightfold at $6 \mathrm{mM}$ ); $\mathrm{NH}_{4} \mathrm{Cl}$ (eightfold with $100 \mathrm{mM}$ ) and $\mathrm{KCl}$ (fourfold with $100 \mathrm{~mm}$ ). Under standard assay conditions with $0.4 \mathrm{mM}-\mathrm{PEP}$, a twofold activation of pyruvate kinase was obtained with the addition of FDP at $0.5 \mu \mathrm{M}$.

Plots of pyruvate kinase activity in situ against PEP were sigmoidal, confirming the homotropic interaction for this substrate (data not shown). The properties of pyruvate kinase in permeabilized cells and homogenates are summarized in Table 5. A value of $0.5 \mathrm{~mm}$-PEP was obtained for the apparent $s_{0.5}$ for the enzyme from germ-tube forming cells. The inclusion of FDP at $0.2 \mathrm{~mm}$ in the assays lowered the $s_{0.5}$ value to $0.4 \mathrm{~mm}$ for the in situ enzyme from germtube forming cells. Similar results were obtained with the enzyme from yeast cells except that the $s_{0.5}$ value for PEP $(1 \mathrm{mM})$ was higher than the value for the enzyme in extracts $(0.6 \mathrm{mM})$.

Hill plots for the enzyme from yeast cells gave similar $h$ values in the in vitro and in situ assays 
(1.90 and 1.95). Pyruvate kinase in vitro and in situ showed similar changes in the $h$ value with the addition of 0.2 mM-FDP ( 1.30 and 1.20 , respectively). With germ-tube forming cells, however, the Hill coefficient $(h=3)$ for the in situ enzyme was higher than the value $(h=2)$ obtained with cell extracts. The high value $(h=3)$ decreased to 1.3 when $0.2 \mathrm{~mm}$-FDP was included in the assays.

Plots of velocity with varying ADP concentrations were hyperbolic (data not shown). When germ-tube forming cells were used, apparent $K_{\mathrm{m}}$ values of $1.6 \mathrm{~mm}$ and $1.4 \mathrm{~mm}$ were obtained with cell extract and permeabilized cells, respectively. For yeast cells, the apparent $K_{\mathrm{m}}$ values were $1.6 \mathrm{~mm}$ and $1.8 \mathrm{~mm}$ (Table 5 ). $V_{\max }$ for pyruvate kinase in both assays was reduced by $50 \%$ with 4 mM-ATP. The apparent $K_{\mathrm{m}}$ value for ADP did not change significantly by the inclusion of $1.96 \mathrm{mM}$-ATP. Dixon plots (not shown) of the inhibition of pyruvate kinase with ATP were non-linear. Pyruvate kinase activity was inhibited $50 \%$ by the presence of $4 \mathrm{mM}$-ATP in all assays.

\section{Properties of phosphofructokinase in situ}

Phosphofructokinase in permeabilized cells and homogenates showed similar profiles for activity versus $\mathrm{pH}$. When assayed with $2.5 \mathrm{~mm}-\mathrm{ITP}$ in either $0.1 \mathrm{M}$-Tris/HCl or $0.1 \mathrm{M}$ imidazole/ $\mathrm{HCl}$, activity at $\mathrm{pH} 6.5$ was 0.13 of the activity at $\mathrm{pH} 7.6$. The enzyme in both preparations was stimulated by: $\mathrm{KCl}$ (twofold with $50 \mathrm{~mm}$ ), $\mathrm{NH}_{4} \mathrm{Cl}$ (fourfold with $20 \mathrm{mM}$ ), $\left(\mathrm{NH}_{4}\right)_{2} \mathrm{SO}_{4}$ (threefold with $20 \mathrm{mM}$ ) and inhibited $50 \%$ by $20 \mathrm{mM}$-sodium phosphate $(\mathrm{pH} 7 \cdot 0$ ). Phosphofructokinase in permeabilized cells and cell extracts of $1 \mathrm{~h}$ germ-tube forming cells had the same stability (half-life of $\sim 30 \mathrm{~h}$ at $4{ }^{\circ} \mathrm{C}$ ) as the in situ yeast enzyme. However, the enzyme in yeast cell homogenates was unstable (half-life of $1.5 \mathrm{~h}$ at $4^{\circ} \mathrm{C}$ ).

The ATP inhibition in situ of phosphofructokinase from $1 \mathrm{~h}$ germ-tube forming cells was dependent upon the Fru 6-P concentration and similar to the inhibition observed in vitro. Under the standard assay conditions, $50 \%$ inhibition of activity was observed with 2 mM-ATP and $9 \mathrm{mM}-\mathrm{ATP}$ when the Fru 6-P concentration in the assay was $0.4 \mathrm{mM}$ and $0.8 \mathrm{mM}$, respectively. When assayed in situ under the former conditions, the inhibition was relieved by either AMP or UMP (at $2 \mathrm{mM}$ ), but not CMP (Fig. 2a). Similar results were obtained with the enzyme from cell extracts (data not shown).
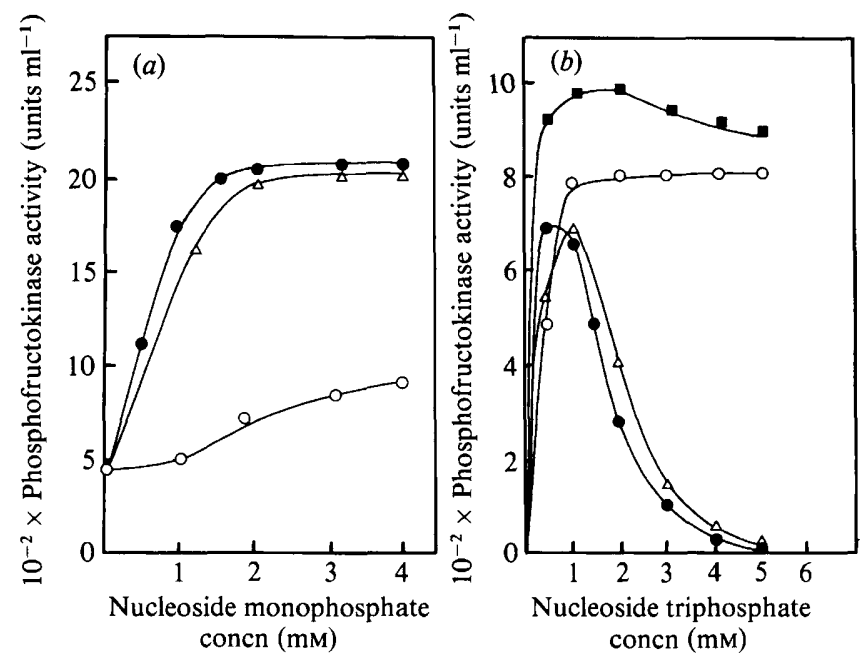

Fig. 2. (a) Effect of nucleoside monophosphates on phosphofructokinase. Varying concentrations of CMP $(O)$, UMP $(\triangle)$ and AMP $(\bigcirc)$ were added to the standard assay containing 2.5 mM-ATP and $0.4 \mathrm{mM}$-fructose 6-phosphate. The in situ enzyme preparation contained $2.3 \times 10^{8}$ germ-tube forming cells $\mathrm{ml}^{-1}$. (b) Comparison of nucleoside triphosphates as substrates for phosphofructokinase. In situ assays were performed as described in Methods with varying concentrations of ATP $(\odot), C T P(\triangle)$, UTP $(\square)$ and ITP $(\bigcirc)$. An enzyme preparation containing $2 \cdot 1 \times 10^{8}$ germ-tube forming cells ml ${ }^{-1}$ was used. 
Table 6. Apparent $K_{\mathrm{m}}$ and $V_{\max }$ values of nucleoside triphosphates for phosphofructokinase

\begin{tabular}{|c|c|c|c|}
\hline \multirow[b]{2}{*}{ Substrate } & \multirow{2}{*}{$\begin{array}{c}\text { Yeast cells } \\
\text { in situ }\end{array}$} & \multicolumn{2}{|c|}{$\begin{array}{l}1 \mathrm{~h} \text { germ-tube- } \\
\text { forming cells }\end{array}$} \\
\hline & & in situ & in vitro \\
\hline & \multicolumn{3}{|c|}{ (a) Apparent $K_{\mathrm{m}}$ (m $\mathrm{M}$ nucleoside triphosphate } \\
\hline ATP & 0.07 & 0.06 & 0.07 \\
\hline ITP & $0 \cdot 28$ & $0 \cdot 30$ & $0 \cdot 31$ \\
\hline UTP & 0.35 & 0.27 & $0 \cdot 30$ \\
\hline \multirow[t]{2}{*}{ CTP } & ND & $0 \cdot 41$ & $0 \cdot 50$ \\
\hline & \multicolumn{3}{|c|}{ (b) $V_{\max }\left(\mu \mathrm{mol} \mathrm{min}^{-1}\right.$ per $10^{10}$ cells $)$} \\
\hline ATP & 40 & 30 & 42 \\
\hline ITP & 43 & 40 & 43 \\
\hline UTP & 30 & 32 & 34 \\
\hline CTP & ND & 31 & 27 \\
\hline
\end{tabular}

Table 7. Kinetic properties of phosphofructokinase in vitro and in situ

Permeabilized cells and homogenates were prepared and assayed as described in Methods and Fig. 3. Hill plots were used to determine $(a)$ the apparent $s_{0.5}$ value and $(b) h$ value for fructose 6-phosphate in assays using either ITP or ATP ( \pm AMP).

\begin{tabular}{|c|c|c|c|}
\hline \multirow[b]{2}{*}{ Substrate } & \multirow[b]{2}{*}{$\begin{array}{l}\text { Yeast cells } \\
\text { in situ } \\
\text { (a) Appar }\end{array}$} & \multicolumn{2}{|c|}{$\begin{array}{l}1 \mathrm{~h} \text { germ-tube- } \\
\text { forming cells }\end{array}$} \\
\hline & & $\begin{array}{l}\text { in situ } \\
\text { value }\end{array}$ & $\begin{array}{l}\text { in vitro } \\
u b-P)\end{array}$ \\
\hline $\begin{array}{l}\text { ITP } \\
\text { ATP + AMP } \\
\text { ATP }\end{array}$ & $\begin{array}{l}0 \cdot 8 \\
1 \cdot 4 \\
2 \cdot 3\end{array}$ & $\begin{array}{r}0.8 \\
1.7 \\
2 \cdot 2 \\
\text { h value }\end{array}$ & $\begin{array}{l}0 \cdot 7 \\
\text { ND } \\
1 \cdot 6\end{array}$ \\
\hline $\begin{array}{l}\text { ITP } \\
\text { ATP + AMP } \\
\text { ATP }\end{array}$ & $\begin{array}{l}2 \cdot 0 \\
3 \cdot 3 \\
4 \cdot 0\end{array}$ & $\begin{array}{l}1 \cdot 6 \\
2 \cdot 2 \\
3 \cdot 0\end{array}$ & $\begin{array}{l}1.9 \\
\text { ND } \\
3.5\end{array}$ \\
\hline
\end{tabular}

ND, Not determined.

The in situ phosphof ructokinase in the germ-tube forming cells exhibited a broad specificity with respect to the phosphate donor (Fig. 2b). ATP, UTP, CTP and ITP were substrates. At a concentration greater than $2 \mathrm{mM}, \mathrm{CTP}$ and ATP markedly reduced the in situ activity while UTP and ITP were without effect. Similar results were obtained with cell extracts. $K_{\mathrm{m}}$ values for the nucleoside triphosphate substrates are shown in Table 6.

Figure 3 shows a representative plot of velocity with varying Fru 6-P concentration for the enzyme from $1 \mathrm{~h}$ germ-tube forming cells. With ATP as the second substrate, the plot was sigmoidal and the co-operativity was decreased by the addition of AMP. Plots with ITP were essentially hyperbolic. Similar results were obtained for the enzyme in homogenates. A comparison of the kinetic properties of phosphofructokinase in vitro and in situ for different types of cells is summarized in Table 7 . 


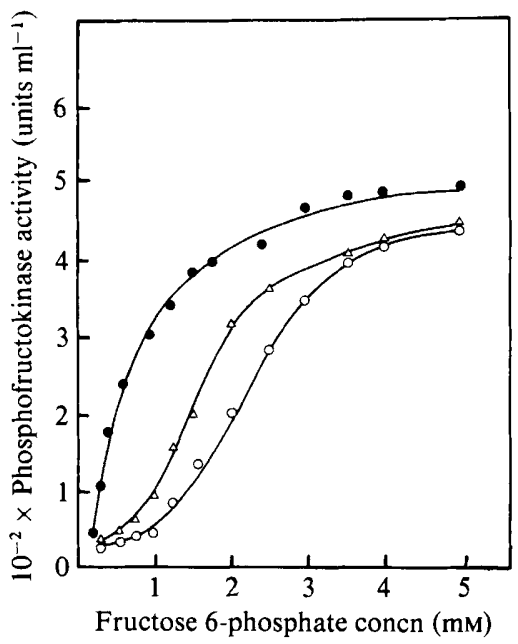

Fig. 3. Effect of fructose 6-phosphate on in situ phosphofructokinase activity. Phosphofructokinase activity was measured with varying Fru 6-P concentrations in assays which contained $0.5 \mathrm{mM}-\mathrm{ATP}$ $(O)$, or $0.5 \mathrm{~mm}$-ATP and $0.5 \mathrm{~mm}$-AMP $(\triangle)$, or $0.5 \mathrm{~mm}$-ITP $(\bigcirc)$. The in situ enzyme preparation contained $2.6 \times 10^{8}$ germ-tube forming cells $\mathrm{ml}^{-1}$.

\section{DISCUSSION}

Numerous reports exist on the permeabilization of $S$. cerevisiae (reviewed by Felix, 1982). By contrast, the optimal conditions for permeabilizing $C$. albicans have not been documented. Notario (1982) and Arnold \& McClellan (1975) have measured in situ exo-1,3- $\beta$-glucanase and trehalase, respectively. However, no assessment of the extent of permeabilization or the utility of the method has been reported.

An extensive survey of different reagents tested singly and in combination established that TET produced yeast cells with the highest in situ Glc-6-P dehydrogenase activity. Different types of $C$. albicans cells responded differently to various combinations of permeabilizing reagents probably because of the differences in the composition of cell walls (Chattaway et al., 1968) and plasma membranes (Marriott, 1975). Exponential phase yeast cells were more resistant than starved yeast cells and germ-tube forming cells. With exponential phase cells the ratio for in situ: in vitro activity varied from 0.50 to 0.80 , while starved and germ-tube forming cells gave values in the range 0.74 to 1.03 . The high in situ phosphatase activity compared with in vitro values suggests that the activity of this enzyme is partially masked in homogenates.

The extensive release of ${ }^{35} \mathrm{~S}$ from labelled cells after treatment with TET $(66 \%$ of the label) shows that the pool of low molecular weight metabolites in permeabilized cells had equilibrated with the extracellular medium. Free glucose found in TET extracts could arise from 1,3- $\beta$ - and $1,6-\beta$-glucanase, amyloglucosidase or trehalase activities. All carbohydrate present in TET extracts could be derived from the wall but only $3-6 \%(\mathrm{w} / \mathrm{w})$ of the $20 \%(\mathrm{w} / \mathrm{w})$ protein extracted could come from this source (P. A. Sullivan, unpublished data). Consistent with observations made with $E$. coli and other yeasts (Felix, 1982) PAGE of TET extracts of $C$. albicans celis confirmed the presence of cytoplasmic proteins.

The in situ measurement of chitin synthase confirmed a previous report (Chiew et al., 1980) that a fourfold increase in enzyme activity occurs during germ-tube formation. Since most chitin synthase in $C$. albicans is in an inactive (proenzyme) form, it is likely that activated enzyme is measured. Both glucan and chitin synthases were assayed with ease after cells were treated with $4 \%(\mathrm{v} / \mathrm{v})$ TET. In contrast to the ATPases, no activity was detected in cells treated with high concentrations of TET. Both the mitochondrial (alkali optimum, oligomycin and dicyclohexyl carbodiimide sensitive) ATPase and plasma membrane (acid optimum) ATPase could be assayed. The activity of both ATPases was similar in homogenates and permeabilized cells. 
These results indicate that membrane bound enzymes and their properties can be studied in permeabilized cells.

The glucosamine-6-phosphate deaminase and GlcNAc kinase were previously shown to increase 25- and 20-fold, respectively, when starved cells of C. albicans were incubated with 2.5 mM-GlcNAc (Shepherd et al., 1980 b; Gopal et al., 1982a). Permeabilization of cells removed from the cells the endogenous hexose phosphates known to interfere with the glucosamine-6phosphate deaminase assays in cell extracts. The 25- and 15-fold increases in activity of the deaminase and kinase activities after $3 \mathrm{~h}$ incubation of cells in $2.5 \mathrm{~mm}$-GlcNAc essentially replicate values obtained with the in vitro assays and show that the induction of enzymes can also be reliably monitored with in situ assays.

Intracellular enzymes are present in high concentrations (Sols \& Marco, 1970) and, thus, protein-protein interactions could change the properties of an enzyme. Therefore, the in situ measurement of enzymes involved in the regulation of metabolism, particularly allosteric enzymes is of interest. Pyruvate kinase from both yeast and germ-tube forming cells was activated in situ twofold by FDP and showed homotropic interactions for PEP (Hill coefficient and $s_{0.5}$ values of approximately 2.0 and $0.5 \mathrm{~mm}$, respectively). Similar properties have been reported for the pyruvate kinase measured in situ in $S$. cerevisiae (Banuelos \& Gancedo, 1978). The $K_{\mathrm{m}}$ of pyruvate kinase from C. albicans for ADP (1.4-1.8 mM) was higher than that reported for the enzyme from $S$. cerevisiae $(0.6 \mathrm{mM})$. Candida albicans phosphofructokinase exhibited the classical allosteric properties described for the enzyme isolated from a number of other sources (Bonnsaeng et al., 1977; Bloxham \& Lardy, 1973; Reeves \& Sols, 1973; Lindell \& Stellwagen, 1968). The degree of co-operativity with respect to Fru 6-P decreased with added AMP. Under similar conditions of assay, the Hill coefficients and $s_{0.5}$ value for Fru 6-P were the same for the in vitro and in situ preparations.

Phosphofructokinase has previously been studied in cell extracts from yeast, germ-tube and mycelial forms of $C$. albicans (Chattaway et al., 1973). The results from the present study have confirmed that the properties of the enzyme from the different types of cells are similar with the exception that no marked differences were found in $V_{\max }$ when ATP rather than ITP was used as the phosphate donor. Further, phosphofructokinase activity remained constant during germtube formation.

Saccharomyces cerevisiae phosphofructokinase accounts for less than $2 \%$ of the rate at which glucose is utilized (Gancedo \& Banuelos, 1979). Yeast cells of C. albicans utilize glucose at a rate of $2.8 \mu \mathrm{mol} \mathrm{min}^{-1}$ per $10^{10}$ cells and approximately $60 \%$ of the assimilated carbon is expired as $\mathrm{CO}_{2}$ (P. K. Gopal, M. G. Shepherd \& P. A. Sullivan, unpublished results). From the amount of phosphofructokinase in $C$. albicans cells it can be calculated that glucose can be metabolized at the rate of $1.2-1.8 \mu \mathrm{mol} \mathrm{min}{ }^{-1}$ per $10^{10}$ cells. Since glucose flux through the Embden-Meyerhof pathway is between 60 and $80 \%$ (Boonsaeng et al., 1977), phosphofructokinase can account for the rate of glucose utilization found with growing yeast cells of $C$. albicans.

The kinetic properties of pyruvate kinase and phosphofructokinase, are similar when measured either in situ or in cell extracts. Thus the in situ method of enzyme analysis is a useful alternative approach. This is especially so when an enzyme is labile such as the phosphofructokinase of $C$. albicans and Candida 107 (Ratledge \& Botham, 1977).

\section{REFERENCES}

ADAMs, B. G. (1972). Method for decryptification of $\alpha$ glucosidase in yeast with dimethyl sulfoxide. Analytical Biochemistry 45, 137-146.

ARNold, W. N. \& MCClellan, M. N. (1975) Trehalose and glycogen levels during the initial stages of growth by Candida albicans. Physiological Chemistry and Physics 7, 369-380.

Banuelos, M. \& Gancedo, C. (1978). In situ study of the glycolytic pathway in Saccharomyces cerevisiae. Archives of Microbiology 117, 197-201.

Bloxham, D. P. \& Lardy, H. A. (1973). Phosphofruc- tokinase. In The Enzymes, vol. 8, pp. 239-278. Edited by P. D. Boyer. New York: Academic Press

Boonsaeng, V., Sullivan, P. A. \& Shepherd, M. G. (1977). Phosphof ructokinase and glucose catabolism of Mucor and Penicillium species. Canadian Journal of Microbiology 23, 1214-1224.

BRAY, G. A. (1960). A simple efficient liquid scintillator for counting aqueous solutions in a liquid scintillation counter. Analytical Biochemistry 1, 279 285.

Broad, T. E. \& Shepherd, M. G. (1970). Purification 
and properties of glucose-6-phosphate dehydrogenase from the thermophilic fungus Penicillium duponti. Biochimica et biophysica acta 198, 407-414.

Castellot, J. J., Miller, M. R. \& Pardee, A. B (1978). Animal cells reversibly permeable to small molecules. Proceedings of the National Academy of Sciences of the United States of America 75, 351-355.

Chattaway, F. W., Bishop, R., Holmes, M. R. \& ODDs, F. C. (1973). Enzyme activities associated with carbohydrate synthesis and breakdown in the yeast and mycelial forms of Candida albicans. Journal of General Microbiology 75, 97-109.

Chattaway, F. W., Holmes, M. R. \& Barlow, A. J. E. (1968). Cell wall composition of mycelial and blastospore forms of Candida albicans. Journal of General Microbiology 51, 367-376.

Chiew, Y. Y., ShePherd, M. G. \& Sullivan, P. A. (1980). Regulation of chitin synthesis during germtube formation in Candida albicans. Archives of Microbiology 125, 97-104.

Dubois, M., Gilles, K. A., Hamilton, J. K., Rebers, P. A. \& SMITH, F. (1956). Colorimetric method for determination of sugars and related substances. Analytical Chemistry 28, 350-356.

Felix, H. (1982). Permeabilized cells. Analytical Biochemistry 120, 211-234.

Flavell, R. B. \& Fincham, J. R. S. (1968). Acetatenonutilizing mutants of Neurospora crassa. Journal of Bacteriology 95, 1063-1068.

Flores-Carreón, A., Larriba, G. \& Sentendreu, R. (1980). Stabilization of chitin synthase of Mucor rouxii and detection of two zymogenic pools. FEMS Microbiology Letters 8, 151-155.

GaCHELIN, G. (1969). A new assay for the phosphotransferase system in Escherichia coli. Biochemical and Biophysical Research Communications 34, 382387.

Gancedo, G. \& Banuelos, M. (1979). The glycolytic pathway in yeast. Study under in situ conditions. In Metabolic Interconversion of Enzymes (4th International Symposium), pp. 198-202. Heidelberg: Springer-Verlag.

Gopal, P., Sullivan, P. A. \& Shepherd, M. G. (1982a). Enzymes of $\mathrm{N}$-acetylglucosamine metabolism during germ-tube formation in Candida albicans. Journal of General Microbiology 128, 2319-2326.

Gopal, P. K., ShePherd, M. G. \& Sullivan, P. A. $(1982 b)$. Glucan synthetase in Candida albicans. Proceedings of the University of Otago Medical School 60, 32-34.

Hess, B. \& Wieker, H. (1974). Pyruvate kinase from yeast. In Methods of Enzymatic Analysis, pp. 778783. Edited by H. U. Bergmeyer. London: Academic Press.

Kornberg, H. L. \& ReEves, R. E. (1972). Correlation between hexose transport and phosphotransferase activity in Escherichia coli. Biochemical Journal 126, 1241-1243.

LEVER, M. (1973). Colorimetric and fluorometric carbohydrate determination with $\rho$-hydroxybenzoic acid hydrazide. Biochemical Medicine 7, 274-281.
Lindell, T. J. \& Stellwagen, E. (1968). Purification and properties of phosphofructokinase from yeast. Journal of Biological Chemistry 243, 907-912.

Lloyd, J. B. \& Whelan, W. J. (1969). An improved method for enzymic determination of glucose in the presence of maltose. Analytical Biochemistry 30, 467470.

LOOMIS, W. F. \& MAGASANIK, B. (1964). The relation of catabolite repression to the induction system for $\beta$ galactosidase in Escherichia coli. Journal of Molecular Biology 8, 417-426.

MARRIOTT, M. S. (1975). Isolation and chemical characterization of plasma membranes from yeast and mycelial forms of Candida albicans. Journal of General Microbiology 86, 115-132.

NotARIO, V. (1982). $\beta$-Glucanases from Candida albicans: purification, characterization and the nature of their attachment to cell wall components. Journal of General Microbiology 128, 747-759.

Pardee, A. B., Jacob, F. \& Monod, J. (1959). The genetic control and cytoplasmic expression of "inducibility" in the synthesis of $\beta$-galactosidase by $E$. coli. Journal of Molecular Biology 1, 165-178.

RACKER, E. (1947). Spectrophotometric measurement of hexokinase and phosphohexokinase activity. Journal of Biological Chemistry 167, 843-854.

Ratledge, C. \& Botham, P. A. (1977). Pathways of glucose metabolism in Candida 107, a lipid accumulating yeast. Journal of General Microbiology 102, 391-395.

Reeves, R. E. \& Sols, A. (1973). Regulation of Escherichia coli phosphofructokinase in situ. Biochemical and Biophysical Research Communications 50, 459-466.

Serrano, R., Gancedo, J. M. \& Gancedo, C. (1973). Assay of yeast enzymes in situ. European Journal of Biochemistry 34, 479-482.

Shepherd, M. G. \& Sullivan, P. A. (1976). The production and growth characteristics of yeast and mycelial forms of Candida albicans in continuous culture. Journal of General Microbiology 93, 361-370.

Shepherd, M. G., Chiew, Y. Y., Ram, S. P. \& Sullivan, P. A. (1980a). Germ-tube induction in Candida albicans. Canadian Journal of Microbiology 26, 21-26.

Shepherd, M. G., Ghazali, H. M. \& Sullivan, P. A. $(1980 b) . N$-Acetyl-D-glucosamine kinase and germtube formation in Candida albicans. Experimental Mycology 4, 147-159.

Sols, A. \& MARCo, R. (1970), Concentrations of metabolites and binding sites. Implication in metabolic regulation. Current Topics in Cell Regulation 2 , 227-274.

Sundaram, S., Sullivan, P. A. \& Shepherd, M. G. (1981). Changes in lipid composition during starvation and germ-tube formation in Candida albicans. Experimental Mycology 5, 140-147.

Weitzman, P. D. J. \& Hewson, J. K. (1973). In situ regulation of yeast citrate synthase: absence of ATP inhibition observed in vitro. FEBS Letters 36, 227 231. 